\title{
ANTERIOR PERCUTANEOUS CERVICAL DISCECTOMY. TWO-YEAR FOLLOW-UP OF A BLUNT TECHNIQUE PROCEDURE
}

\author{
DISCOTOMIA CERVICAL PERCUTÂNEA ANTERIOR. DOIS ANOS DE ACOMPANHAMENTO \\ DE UM PROCEDIMENTO COM TÉCNICA ROMBA
}

\section{DISCECTOMÍA CERVICAL ANTERIOR PERCUTÁNEA. DOS AÑOS DE SEGUIMIENTO DE UNA TÉCNICA ROMA}

\begin{abstract}
Jorge Felipe Ramírez león ${ }^{1,2,3}$,José Gabriel Rugeles Ortiz, Carolina Ramírez Martínez ${ }^{1,2,3}$, Enrioue Osorio Fonseca ${ }^{1,2,3}$, Nicolás Prada Ramírez ${ }^{4}$,
\end{abstract} Gabriel Oswaldo Alonso Cuéllar ${ }^{1}$

\author{
1. Centro de Columna, Cirugía Mínima Invasiva, Bogotá, Colombia. \\ 2. Centro de Cirugía de Mínima Invasión (Cecimin), Bogotá, Colombia. \\ 3. Clínica Reina Sofía, Organización Sanitas Internacional, Bogotá, Colombia \\ 4. Clínica Foscal Internacional, Bucaramanga, Colombia.
}

\begin{abstract}
Objective: To report the outcomes of non-endoscopic percutaneous cervical discectomy by anterior blunt approach for the treatment of degenerative disc disease. Methods: A review of the medical records of patients with axial cervical pain resulting from degenerative disc disease and treated with discectomy and percutaneous nucleoplasty by anterior blunt approach with radiofrequency source was carried out. The data were evaluated according to modified MacNab and pre- and postoperative VAS criteria at 3, 12 and 24 months. Results: Sixty-two procedures were performed in 48 patients between 2008 and 2014. The mean age of the population was 52.4 years. MacNab results were $84.6 \%, 92.3 \%$, and $89.2 \%$ improvement (excellent and good results) at 3, 12 and 24 months, respectively. The VAS changed from 7.4 to 2.3 two years after the procedure, showing a statistically significant difference $(p=0.000)$. There were no major complications or re-interventions related to the technique. Conclusions: Anterior non-endoscopic discectomy and nucleoplasty for the treatment of discogenic axial cervical pain may be an effective alternative to open surgery. In the two-year follow-up, our blunt technique proved to be a safe procedure with no approach-related complications, and provided outcomes comparable to those reported using the original needle technique.
\end{abstract}

Keywords: Spine; Intervertebral disc degeneration; Neck pain; Diskectomy, percutaneous; Minimally invasive surgical procedures.

\section{RESUMO}

Objetivo: Relatar os resultados de discotomia percutânea não endoscópica por acesso anterior rombo para tratamento de doença degenerativa do disco. Métodos: Realizou-se uma revisão dos prontuários clínicos de pacientes com dor cervical axial decorrente de doença degenerativa do disco e tratados com discotomia e nucleoplastia percutâneas não endoscópicas por acesso anterior rombo com fonte de radiofrequência. Os dados foram avaliados de acordo com MacNab modificado e os critérios pré e pós-operatórios da EVA aos 3 , 12 e 24 meses. Resultados: Um total de 62 procedimentos foi realizado em 48 pacientes entre 2008 e 2014. A média de idade da população foi de 52, 4 anos. Os resultados de MacNab obtidos foram 84,6\%, 92,3\% e 89,2\% de melhora (resultados excelentes e bons) aos 3,12 e 24 meses, respectivamente. A EVA passou de 7,4 para 2,3 dois anos depois do procedimento, mostrando diferença estatisticamente significante ( $p$ $=0,000)$. Não houve complicações importantes ou reintervenções relacionadas com a técnica. Conclusões: A discotomia e nucleoplastia não endoscópicas anteriores para tratamento da dor cervical axial discogênica podem ser uma alternativa efetiva à cirurgia aberta. Nos dois anos de acompanhamento, nossa técnica romba provou ser um procedimento seguro, sem complicações relacionadas com o acesso e proporcionou resultados comparáveis aos relatados quando se usa a técnica original com agulha.

Descritores: Coluna vertebral; Degeneração do disco intervertebral; Cervicalgia; Discotomia percutânea; Procedimentos cirúrgicos minimamente invasivos.

\section{RESUMEN}

Objetivo: Reportar los resultados de la discectomía percutánea no endoscópica a través de abordaje anterior romo para el tratamiento de la enfermedad degenerativa del disco. Métodos: Se realizó una revisión de las historias clínicas de los pacientes con dolor cervical axial resultante de enfermedad degenerativa del disco y tratados con discectomía y nucleoplastia percutáneas no endoscópicas por abordaje anterior romo con fuente de radiofrecuencia. Los datos fueron evaluados de acuerdo con MacNab modificado y los criterios pre y postoperatorios de EVA a los 3, 12 y 24 meses. Resultados: Se realizaron un total de 62 procedimientos en 48 pacientes entre 2008 y 2014 . La edad promedio de la población fue de 52,4 años. Los resultados de MacNab obtenidos fueron 84,6\%, 92,3\% y 89,2\% de mejora (resultados excelentes y buenos) a los 3, 12 y 24 meses, respectivamente. La EVA cambió de 7,4 a 2,3 dos años después del procedimiento, mostrando diferencia estadísticamente significativa $(p=0,000)$. No hubo complicaciones importantes o reintervenciones relacionadas con la técnica. Conclusiones: La discectomía y nucleoplastia no endoscópicas anteriores para el tratamiento del dolor cervical axial discogénico pueden ser una alternativa efectiva a la cirugía abierta. En los dos años de seguimiento, nuestra técnica roma demostró ser un procedimiento seguro, sin complicaciones relacionadas con el abordaje y proporcionó resultados comparables a los reportados cuando se usa la técnica original con aguja.

Descriptores: Columna vertebral; Degeneración del disco intervertebral; Dolor de cuello; Discectomía percutánea; Procedimientos quirúrgicos mínimamente invasivos. 


\section{INTRODUCTION}

Neck pain is a common reason for medical consultation and disability in adults. ${ }^{1}$ Its prevalence is estimated at between $26 \%$ and $71 \%{ }^{2}$ and the number of people consulting the doctor, and requiring surgery to treat the pain, is growing. ${ }^{2,3}$ The surgical treatment is still controversial, therefore it should only be carried out when all conservative medical options have failed. The most common surgical procedure for discogenic cervical pain is open discectomy by the anterior approach; however, this type of technique is associated with complication rates of around $4 \%$, and mortality rates of between $0.14 \%$ and $0.42 \%$. 3.4 By contrast, minimally invasive percutaneous techniques provide benefits such as smaller incisions, shorter hospitalization times, less postoperative pain, and faster recovery, ${ }^{5}$ with complication rates of below $1 \% .6,7$

One minimally invasive treatment for axial cervical pain is percutaneous non-endoscopic cervical discectomy and nucleoplasty. This treatment works on a principle of producing sufficient intradiscal temperatures to promote annular collagen shrinkage, nucleus dehydration, and nociceptor ablation in the posterior annulus area, resulting in relief of pain. ${ }^{8}$ The technique is supplemented with mechanic nucleotomy, with the aim of achieving total decompression of the nerve structures. ${ }^{9}$ The first report of the technique was that of Siebert ${ }^{10}$ and Choy ${ }^{11}$, who used a discal decompression procedure with laser through an anterior percutaneous approach, previously described by Tajima et al. ${ }^{12}$

Even though cervical percutaneous disc decompression (PCDD) has been reported as an effective technique with low complication rates, $7,10,11,13-15$ the approach involves advancing a spinal needle through the neck from the anterior to the posterior zone. This carries a high risk of puncture or lesion to vital structures, such as the carotid artery, internal jugular vein, trachea and esophagus, as well as possible complications of hematoma due to damage to the blood vessels, nerve puncture headache, and infections. These factors make the learning curve longer, and despite the benefits, the technique is not widely used. ${ }^{16}$ We hypothesize that the use of blunt entry instruments helps minimize the risk of iatrogenic lesion and enhances the safety and effectiveness margins of PCDD.

The purpose of this study is to report the outcomes and complication rates, over a two-year follow-up, of percutaneous non-endoscopic discectomy and nucleoplasty with a blunt approach, in patients with discogenic axial cervical pain without radiculopathy.

\section{METHODS}

\section{Participants}

A retrospective study was conducted of the clinical charts of patients whose reason for consultation was axial cervical pain due to degenerative disc disease, and who underwent surgery using percutaneous non-endoscopic discectomy and nucleoplasty with a radiofrequency (RF) energy source and a blunt approach. The inclusion criteria were medical charts of patients with axial cervical pain with more than six months of evolution, with no response to medical treatment, and imaging results showing cervical degenerative disc disease and contained hernia. The study excluded medical charts of patients showing symptoms and imaging consistent with radiculopathy, stenosis, spondylolisthesis, facet arthrosis, and previous surgery, and those whose medical charts did not show complete assessment criteria.

\section{Procedure}

The patient was placed in the supine position with the neck hyperextended. Lordosis was supplemented by placing a pillow under the shoulders. Mechanical hyperextension was not used in any case. We identified and marked affected level, the midline, and the medial line of the sternocleidomastoid muscle (SCM) using C-arm fluoroscopy. The entry point was two to three centimeters from the midline towards the SCM (Figure 1). By applying firm pressure with the finger on the space between the SCM and the trachea, the assistant surgeon displaced the esophagus and the trachea medially, and the neurovascular bundle laterally. Between five and $10 \mathrm{cc}$ of local anesthesia and $1 \%$ lidocaine were applied, supplemented with light sedation.
As a variation from the original technique, instead of advancing directly into the disc with the spine needle, a small skin incision $(4 \mathrm{~mm})$ was made, and a blunt cannula and dilator from the Disc- $F X^{\circledR}$ System (Elliquence LLC. NYC, US) were inserted (Figure 2). In order to place the tip of the dilator in front of the disc, it was inserted by turning gently (Figure 3). Once the correct position of the cannula tip on the anterior edge of the annulus was verified, the dilator was removed and an 18-gauge spine needle was inserted through the cannula (Figure 4). This maneuver ensured safe entry of the needle, avoiding the risk of vascular lesion to the structures in the anterior part of the neck. With the needle located in the posterior third of the disc, discography was performed.

The needle was then removed and a trephine was inserted through the same cannula, to perform the annulotomy. Next, grasping forceps, from the same system, were used to perform the mechanical nucleotomy (Figure 5). Finally, thermal therapy was performed using the bipolar electrode of the Disc-FX ${ }^{\circledR}$ System (Elliquence LLC. NYC, US) plugged into a Surgi-Max high-frequency generator (Elliquence LLC. NYC, US) in default mode: bipolar hemo for annulus modulation, and bipolar turbo for nucleus dehydration, at a power setting of 25 for 6 seconds each shot (Figure 6).

The same surgical team performed the technique in all cases. In cases of disc pathology at more than one level, the disc was approached through the same incision. Before removing the cannula, a mix of local anesthetic and corticosteroid was injected. The incision was closed with a stitch. The patient was discharged one hour after the procedure, with antibiotic and anti-inflammatory medication for eight days. Postoperative follow-ups were conducted one day, eight days, three months, twelve months and twenty-four months after the procedure.

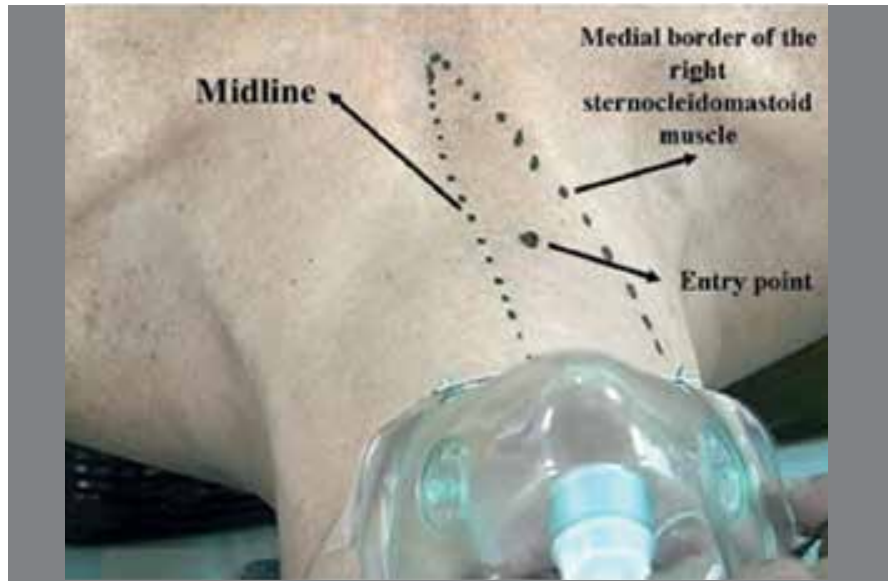

Figura 1. Point of entry. Anatomical landmarks for a safe advance to the cervical intervertebral disc.

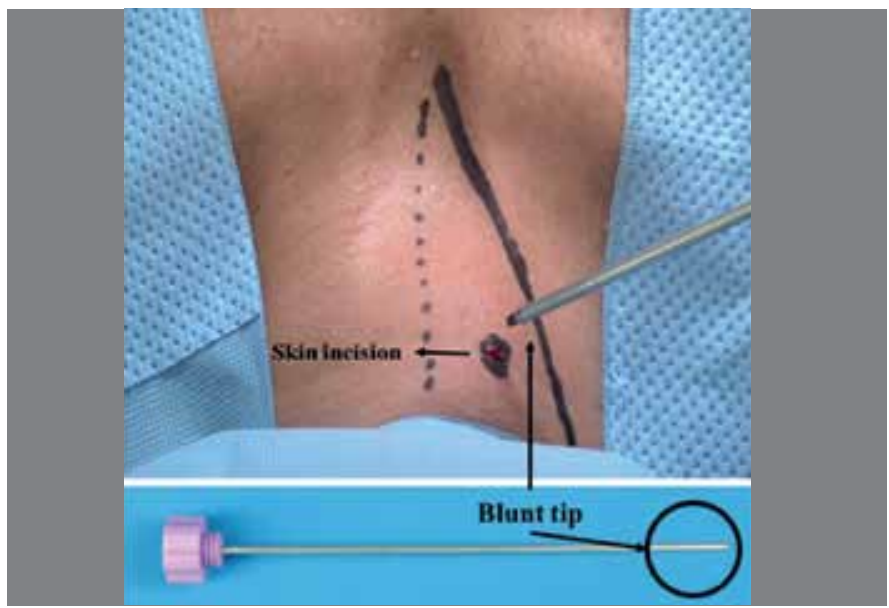

Figura 2. Skin incision ( $3 \mathrm{~mm})$ and dilator with blunt tip. 


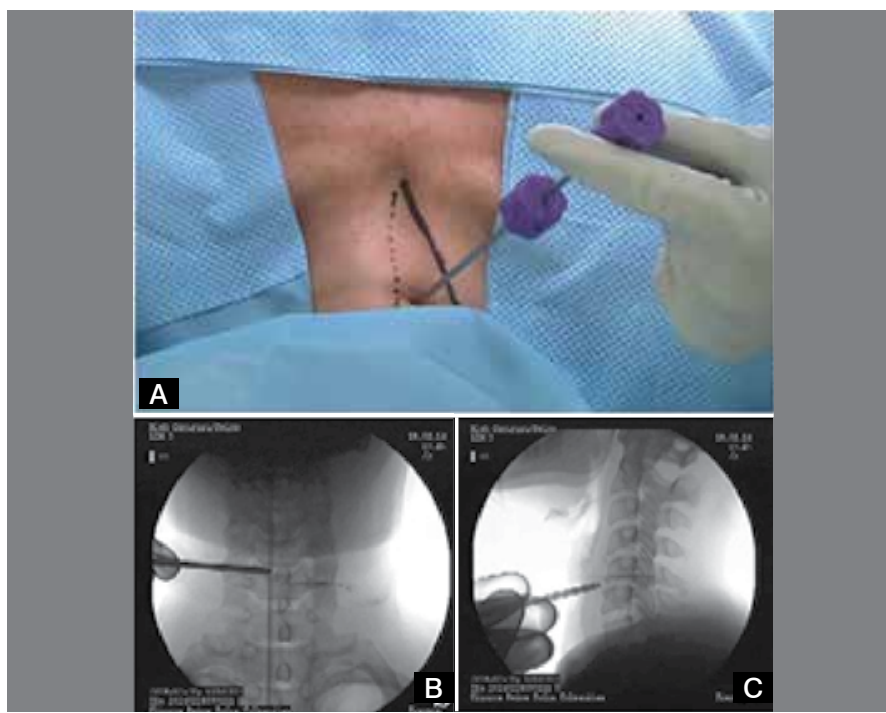

Figura 3. External view of the advance with blunt-tipped cannula within the intervertebral disc. With soft circular movements, the cannula is advanced to the anterior edge of the annulus (A). Anteroposterior (B) and lateral (C) fluoroscopic monitoring.

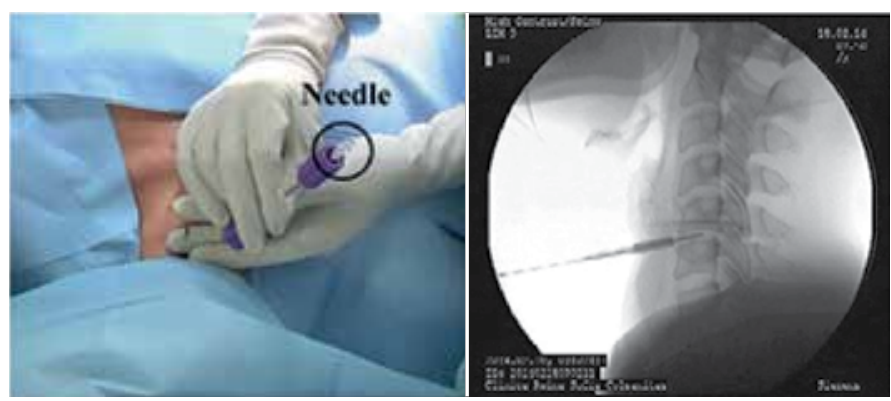

Figura 4. Technique variation. The needle is not advanced directly into the disc but rather through the cannula of the system.
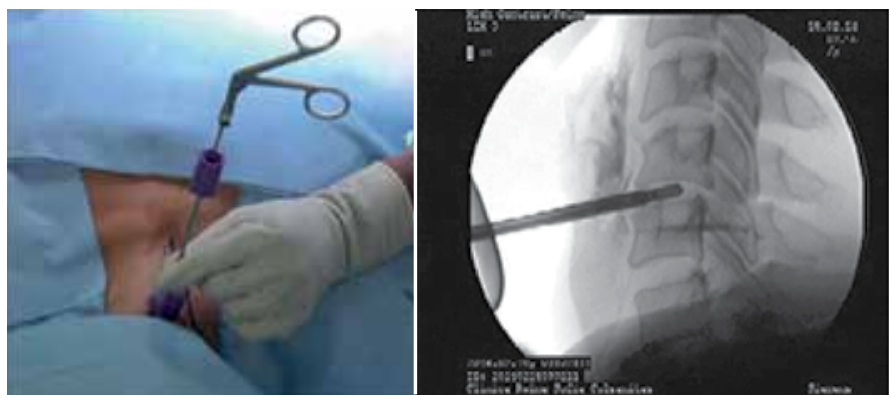

Figura 5. Mechanized nucleotomy.

\section{Measures}

Data were gathered from the patients. Before the surgery, patients were asked to rate their pain on a scale of 0 to 10 (VAS score). Then, at three months, twelve months and twenty four months after the procedure, the patients were again asked to rate their pain using two types of evaluation: pain perception (VAS) and evaluation of improvement (MacNab criteria). Significant postoperative clinical improvement is based on an excellent and good outcome on the MacNab criteria. ${ }^{17}$ The collection of medical charts and other data were carried out by company independent from the researchers.

\section{Statistical analysis}

Data analysis was performed using the statistical software R 3.1.1 for Windows 8. Demographic parameters and descriptive statistics of the variables were established. The descriptive statistics was determined, and the Wilcoxon test for related pairs was applied. The statistical significance was $p<0.05$.

\section{RESULTS}

From June 2008 to March 2014, a total of 62 anterior non-endoscopic discectomy and nucleoplasty procedures were performed in 48 patients with axial cervical pain, using a blunt percutaneous technique. The sex distribution was 59\% $(n=28)$ male, and $41 \%(n=20)$ female. The average age of the sample was 52.4 years $(S D=11.615)$, and the age range was 35.4 to 74.7 years. The average duration of the surgery was 50.6 minutes $(S D=29.33)$.

The MacNab criteria results at 3 months were excellent and good (improvement) $84.6 \%$, fair $15.4 \%$, and poor $0 \%$. At the $12-$ month follow-up, the results were excellent and good $92.3 \%$, and fair $7.7 \%$. At the 24-month follow-up, the results were excellent and good $89.2 \%$, and fair $10.8 \%$. Pain perception expressed by the VAS score improved from $7.4(\mathrm{SD}=1.162)$ pre-op to $2.3(\mathrm{SD}=1.653)$ 12-months post-op, and $2.3(\mathrm{SD}=1.690) 24$-months post-op, showing a statistically significant difference $(p=0.000)$ in pain before surgery, and two years after surgery.

There were no reports of major complications associated with the approach or procedure, such as vascular injury, infection, dural tear, adjacent segment or instability. A reintervention was not required in any of the cases. At the two-year follow-up, the rates of complications and repeat surgery were both $0 \%$.

\section{DISCUSSION}

Percutaneous non-endoscopic discectomy and nucleoplasty by the anterior approach is a technique that combines the intradiscal thermal effect with mechanical nucleus resection (decompression), aiming to achieve ablation and decompression of the pain-generating nerve structures. ${ }^{18}$ The results obtained in this case series showed a significant postoperative clinical improvement in axial cervical pain perception in the second year, with no major complications, in patients treated with this non-endoscopic discectomy and nucleoplasty technique using our blunt approach.
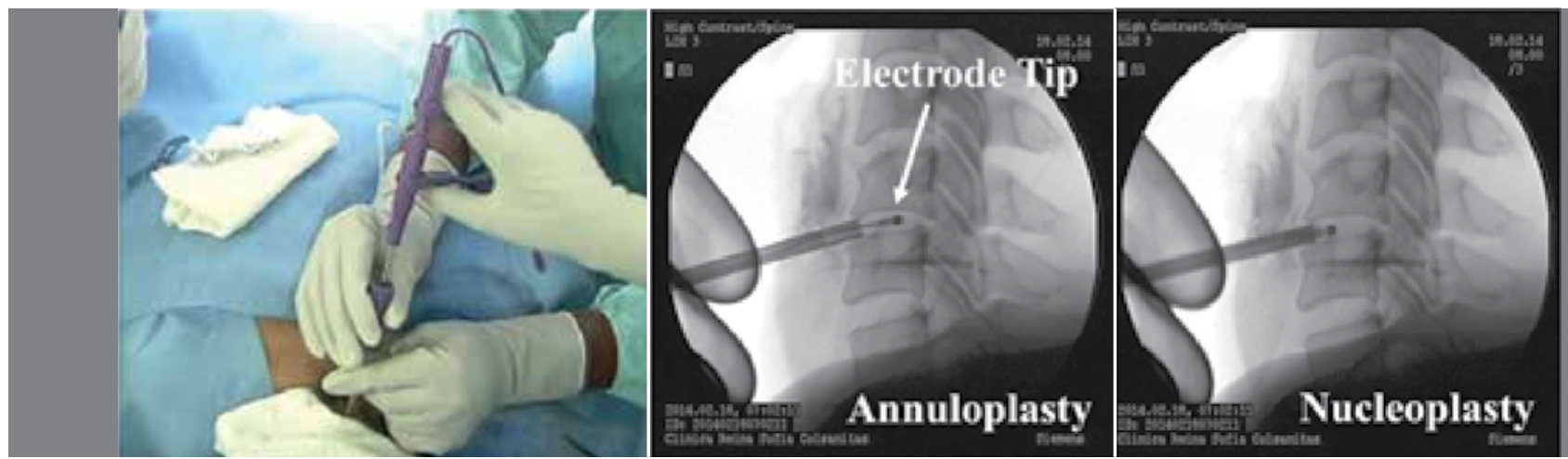

Figura 6. Cervical non-endoscopic thermodiscoplasty by the anterior approach. Annuloplasty and nucleoplasty using bipolar radiofrequency. 
The effectiveness of PCDD via the anterior percutaneous approach in cervical discogenic pain management has been reported by different authors employing laser or RF. In the case of RF, reports have shown high patient satisfaction, with $77 \%$ to $83 \%$ excellent or good results, according to the MacNab criteria. ${ }^{13-15,18}$ For VAS, Sim ${ }^{18}$ reported an improvement from 9.3 to 3.4 at the six-month follow-up, and Schubert showed an improvement from 8.3 to 2.5 in a two-year follow-up. ${ }^{19}$ Likewise, the use of laser - an analogous technology to the RF used in this study - showed satisfaction rates of around $50 \%{ }^{20}$ and $90 \%{ }^{7}$ These results showing improvement are comparable to the effectiveness rate obtained in this report, even with the technique modification, which suggests that varying the technique would not alter the patients' satisfactory results.

With regard to complications during the implementation of the different intradiscal thermal therapies, and those associated with the anterior percutaneous approach, it is important to mention the complication reported by Choy and Fejos, ${ }^{7}$ who presented a retropharyngeal abscess in one patient out of 93 (1\%). Similarly, Ramirez et al. ${ }^{21}$, in a case study with 236 patients, reported three cervical hematomas and two carotid lesions (2\%). Finally, Schubert and Merk presented one case of hoarseness in 95 patients. ${ }^{19}$ Regarding other techniques of cervical pain treatment, which use the anterior percutaneous approach instead, we must emphasize the major complications reported by Tzaan, ${ }^{17}$ who showed lesion of the carotid artery in one out of $107(1 \%)$ patients submitted to endoscopic discectomy.

The results of this technique variation were compared to those reported in the literature for the original percutaneous technique, and their rate of complications. We concluded that although the original technique, when appropriately implemented by an expert surgeon, carries a lower risk of complications, the technique variation reported herein could be an alternative for expert surgeons who wish to increase their safety margin, or for surgeons in the latter stages of the learning curve who wish to further develop their expertise.

One limitation of this study is that it is a retrospective observational study. It is important to conduct a clinical trial to compare the two techniques in a prospective manner, and with a larger sample, to determine the results of each technique when performed by the same surgical team with extensive expertise. It would also be interesting to review the results of the technique variation employed in endoscopic cervical techniques for the treatment of migrated disc herniation and foraminal stenosis.

\section{CONCLUSIONS}

Anterior percutaneous non-endoscopic discectomy and nucleoplasty for the treatment of discogenic axial cervical pain has been reported as an effective alternative to cervical open surgery. Our blunt technique proved to be a safe procedure, with no major complications, and provided outcomes comparable to those reported using the original technique with needle, in a two-year follow-up period.

Dr. Ramírez, Dr. Rugeles, Dr. Ramírez and Dr. Prada are consultant for Elliquence. Dr. Osorio, and Dr Alonso report no conflicts.

CONTRIBUTION OF THE AUTHORS: This manuscript, which is a multi-institutional study, has six authors. Each author made significant individual contributions to this manuscript. JFRL (0000-0003-2145-0417) and GOAC (0000-0001-7350-489X) were the main contributors to the writing of the manuscript. JFRL, JGR, and CR performed the surgical procedures and patient follow-up and gathered the clinical data. JFRL, GA NP and EO evaluated the data from the statistical analysis. GA and NP performed the literature review, revised the manuscript, and contributed to the intellectual concept of the study.

\section{REFERENCES}

1. Falco FJ, Manchikanti L, Datta S, Wargo BW, Geffert S, Bryce DA, et al. Systematic review of the therapeutic effectiveness of cervical facet joint interventions: an update. Pain Physician. 2012;15(6):E839-68.

2. Carragee EJ, Hurwitz EL, Cheng I, Carroll LJ, Nordin M, Guzman J, et al. Treatment of neck pain: injections and surgical interventions: results of the Bone and Joint Decade 2000-2010 Task Force on Neck Pain and Its Associated Disorders. Spine. 2008;33(4 Suppl):S153-69.

3. Wang MC, Chan L, Maiman DJ, KreuterW, Deyo RA. Complications and mortality associated with cervical spine surgery for degenerative disease in the United States. Spine. 2007;32(3):342-7.

4. Skolasky RL, Thorpe RJ Jr, Wegener ST, Riley LH 3rd. Complications and mortality in cervical spine surgery: racial differences. Spine. 2014;39(18):1506-12.

5. Lee SH, Lee JH, Choi WC, Jung B, Mehta R. Anterior minimally invasive approaches for the cervical spine. Orthop Clin North Am. 2007;38(3):327-37.

6. Hellinger J. Complications of non-endoscopic percutaneous laser disc decompression and nucleotomy with the neodymium: YAG laser $1064 \mathrm{~nm}$. Photomed Laser Surg. 2004;22(5):418-22.

7. Choy DS, Fejos AS. Cervical disc herniations and percutaneous laser disc decompression: a case report. Photomed Laser Surg. 2004;22(5):423-5.

8. Ramírez JF, Rugeles JG, Barreto JA, Alonso GO. Intradiscal temperature variation resulting from radiofrequency thermal therapy. Cadaver study. Acta Ortop Mex. 2014;28(1):12-8.

9. Hellinger S. Disc-FX - A treatment for discal pain syndromes combining a manual and radiofrequency-assisted posterolateral microtubular decompressive nucleotomy. Europ Musculoskeletal Rev. 2011;6:100-4

10. SiebertW. Percutaneous laser discectomy of cervical discs: preliminary clinical results. J Clin Laser Med Surg. 1995;13(3):205-7.
11. Choy DS. Techniques of percutaneous laser disc decompression with the Nd:YAG laser. J Clin Laser Med Surg. 1995;13(3):187-93.

12. Tajima T, Sakamoto H, Yamakawa H. Diskectomy cervicale percutanee. Rev Med Orthop. $1989 ; 17: 7-10$

13. Yang B, Xie J, Yin B, Wang L, Fang S, Wan S. Treatment of cervical disc herniation through percutaneous minimally invasive techniques. Eur Spine J. 2014;23(2):382-8.

14. Yan D, Li J, Zhu H, Zhang Z, Duan L. Percutaneous cervical nucleoplasty and percutaneous cervical discectomy treatments of the contained cervical disc herniation. Arch Orthop Trauma Surg. 2010;130(11):1371-6.

15. Gangi A, Tsoumakidou G, Buy X, Cabral JF, Garnon J. Percutaneous techniques for cervical pain of discal origin. Semin Musculoskelet Radiol. 2011;15(2):172-80.

16. Lee SH, Kim KT, Jeong BO, Seo EM, Suk KS, Lee JH, et al. The safety zone of percutaneous cervical approach: a dynamic computed tomographic study. Spine. 2007;32(20):E569-74.

17. Tzaan WC. Anterior percutaneous endoscopic cervical discectomy for cervical intervertebral disc herniation: outcome, complications, and technique. J Spinal Disord Tech. 2011;24(7):421-31.

18. Sim SE, Ko ES, Kim DK, Kim HK, Kim YC, Shin HY. The results of cervical nucleoplasty in patients with cervical disc disorder: a retrospective clinical study of 22 patients. Korean J Pain. 2011;24(1):36-43.

19. Schubert M, Merk S. Retrospective evaluation of efficiency and safety of an anterior percutaneous approach for cervical discectomy. Asian Spine J. 2014;8(4):412-20.

20. Knight MT, Goswami A, Patko JT. Comparative outcome of Holmium: YAG and KTP laser disc ablation in degenerative cervical disc disease: results of an ongoing study. Ortop Traumatol Rehabil. 2000;2(2):39-43.

21. Ramirez J, Rugeles J. Enfermedad cervical degenerativa. Tratamiento mínimamente invasivo. In: XII Congreso Iberolatinoamericano de Columna (SILACO), Valencia, España, 2013 